последующее ее восстановление в $\mathrm{Cu}(\mathrm{I})$ на катоде, увеличить выход по току $\mathrm{Cu}$ и уменьшить выход по току $\mathrm{Cl}$.

Для выделения меди из отработанных травильных растворов нами предложен двухкамерный электролизер с катодом и анодом, изготовленными из нержавеющей стали. В катодную камеру заливали отработанный травильный раствор, следующего состава, г/дм ${ }^{3}: 270 \mathrm{Cu}, 27 \mathrm{NH}_{4} \mathrm{Cl}, 11,6 \mathrm{HCl}$. В качестве анолита использовали раствор $200 \mathrm{r} / \mathrm{дm}^{3} \mathrm{Na}_{2} \mathrm{SO}_{4}$. Электроэкстракцию вели при плотности тока $650 \mathrm{~A} / \mathrm{M}^{2}$, силе тока $350 \mathrm{MA}$, и напряжении $200 \mathrm{~B}$. Процесс вели в течение 4 ч. В результате получена металлическая медь, выход по току составил более 90 \%.

1. R.H. Clark, Handbook of Printed Circuit Manufacturing, Springer Science \& Business Media (2012).

2. US EPA Guides to Pollution Prevention the Printed Circuit Board Manufacturing Industry, A/625/7-90/007 (1990).

\title{
NOVEL METHOD OF SILICON SYNTHESIS BY CVD
}

\author{
Shishkin R.A., Kudyakova V.S., Yuferov Y.V., Zykov F.M. \\ Ural federal University named after the first President of Russia B. N. Yeltsin, \\ Yekaterinburg, Russia \\ "E-mail: roman.shishkin@urfu.ru
}

Semiconductor silicon nanowires due to a combination of unique electronic, optical and mechanical properties as well as its geometry could be applied in various technologies connected with solar cells production [1], electronic devices in medical equipment [2], the anode of lithium electrochemical cell [3].

The present paper is concerned with a silicon nanowires novel CVD synthesis technology.

The silicon nanowires synthesis was carried out at the laboratory tube furnace. The CVD process has two stages: formation of metastable aluminum monofluoride within the reaction of aluminum and aluminum trifluoride; reduction of silica with deposition of silicon.

Anhydrous aluminum trifluoride and the aluminum mixture were used as raw materials. The mixture was heated in an inert atmosphere to the temperatures $950-$ $1200{ }^{\circ} \mathrm{C}$. This route affords the metastable aluminum monofluoride, which reacted with a silica powder. As the resulting needle like outgrowth was observed (figure 1).

$$
2 A l^{(l)}+A l F_{3}^{(g)}=3 A l F^{(g)}
$$



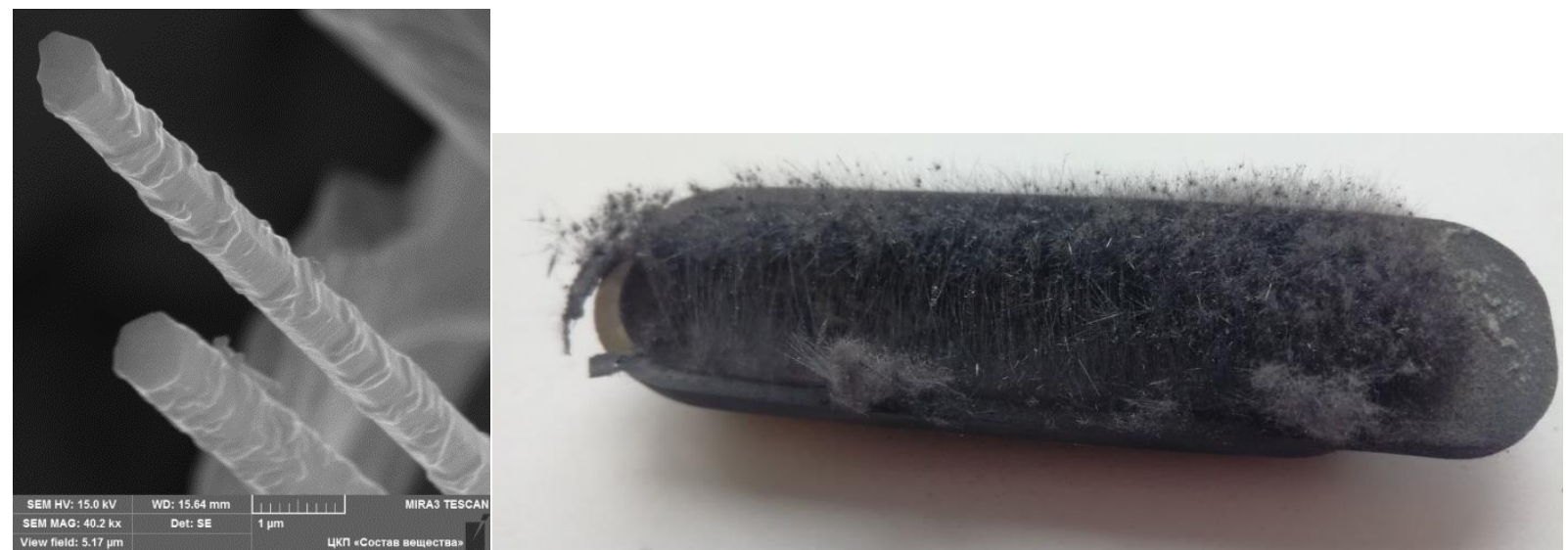

Fig. 1. The image of as synthesized silicon nanowires

Silica reduction mechanism by metastable aluminum monofluoride is still to be considered. According to the thermodynamical calculations, the most probable path could be described by the following reaction:

$$
3 \mathrm{SiO}_{2}+6 \mathrm{AlF}^{(g)}=3 \mathrm{Si}+2 \mathrm{AlF}_{3}^{(g)}+2 \mathrm{Al}_{2} \mathrm{O}_{3} \Delta G_{1100{ }^{\circ} \mathrm{C}}=-124,679 \text { кДж/моль (2) }
$$

The specific capacity of GS- 16 with a $1,74 \%$ silicon nanowires addition anode material is $339,0 \mathrm{~mA} * \mathrm{~h} / \mathrm{g}$ at the first cycle. The value of specific capacity has fallen to the 7 th cycle and the parameter is equal to $190,4 \mathrm{~mA}^{*} \mathrm{~h} / \mathrm{g}$.

1. Lee H. S., Suk J. et al., Scientific Reports, 8(1), 3504 (2018)

2. Peng F., Su Y. et al., Accounts of Chemical Research, 47 (2), 612-623 (2014)

3. Polat B.D., Keles O., ECS Transactions, 64(22), 47-55 (2015) 